УДК 352/354.07/.08:316.422]:005.591](477)(045)

DOI https://doi.org/10.32838/2663-6468/2020.2/05

\title{
Таран E.I.
}

Національна академія державного управління при Президентові України

\section{СПІВВІДНОШЕННЯ ПОНЯТЬ «ДЕРЖАВНЕ УПРАВЛІННЯ», «ПУБЛІЧНЕ АДМІНІСТРУВАННЯ» ТА «ПУБЛІЧНЕ УПРАВЛІННЯ» У ТРАНСФОРМАЦЙНИХ ПРОЦЕСАХ УКРАЇНИ}

У статті проаналізовано співвідношення понять «державне управління», «публічне адміністрування» та «публічне управління», подано їх визначення, висвітлено спільні риси та відмінності.

Трансформаційні прочеси, які відбуваються в Україні, та тї илях до європейського співтовариства зумовлюють необхідність перегляду ролі держави в суспільних відносинах. Модель державного управління, яка існувала за часів командно-адміністративної системи, не в змозі задовольнити потреб сучасного суспільства.

Розвиток громадянського суспільства та поширення демократичних иінностей спричинили невдоволення громадян великою кількістю державних установ та невисокою якістю послуг, які иі установи надавали. Через ие уряди розвинених країн були вимушені у XX $\mathrm{cm}$. провести низку реформ, які б покрашували роботу изи органів у напрямі задоволення потреб населення. Так, традиційні механізми соиіального управління трансформувалися з підходів «наказувати і контролювати» на «мотивувати і отримувати результат».

Це призвело до появи нової форми управління в публічному секторі - публічного адміністрування, що стало закономірним кроком у розвитку державного управління.

Незважаючи на те, що визначення держсавного управління і публічного адміністрування дуже схожі, основною відмінністю в них є те, що державне управління належить до авторитарного виду управління, а публічне адміністрування - до демократичного. У державному управлінні об 'єктом виступає держава, а в публічному адмініструванні об 'єктом є суспільство.

Подальща трансформація процесів управління в державі призвела до того, щчо публічне адміністрування перетворилося на розвинену модель публічного управління. Таким чином, державне управління трансформувалося в публічне адміністрування, яке, своєю чергою, стало етапом, що пройшло управління від державного до публічного.

У результаті проведеного аналізу визначено, що трансформаиійні процеси в Украйні вимагають від неї дослідження найкраших зарубіжних тенденцій і практик, аналізу їх позитивних результатів та адаптаџії їх використання до начіональних особливостей намої держави.

Такий підхід має сформувати модель публічного управління, яка зможе відповідати очікуванням громадян та забезпечить інтереси головних учасників суспільного процесу.

Ключові слова: державне управління, публічне адміністрування, публічне управління, публічний, управління.

Постановка проблеми. Сучасні трансформаційні процеси, що відбуваються в Україні, та iï шлях до європейського співтовариства зумовлюють необхідність перегляду ролі держави в суспільних відносинах. Модель державного управління, яка існувала за часів командно-адміністративної системи, не задовольняє потреб сучасного суспільства. Європейський напрям розвитку України визначає ії̈ перехід до європейської цивілізаційної моделі, а це складний шлях до політично організованого та відповідального суспільства, в якому поступово відбувається підвищення ділової активності та політичної участі громадян, забезпечення їхніх прав і свобод.
Така ситуація вимагає перегляду взаємовідносин між державою і громадянами. Для вирішення цих завдань має поліпшитися організація роботи органів державного управління та місцевого самоврядування.

Для розуміння цих процесів необхідним є узагальнення підходів до розділення понять «державне управління», «публічне адміністрування» та «публічне управління», а також обгрунтування необхідності переходу від концепції «державного управління» до «публічного управління».

Аналіз останніх досліджень і публікацій. Питання, які пов'язані з державним управлінням, у роботах розглядалися такими дослідниками, як 
А. Авер'янов, Г. Атаманчук, М. Міненко, О. Оболенський, Ю. Сурмін та ін. Публічному адмініструванню присвячені роботи І. Грицяк, В. Коваленка, А. Колодія, Н. Мельтюхової та інших. Серед дослідників публічного управління можемо виділити Л. Гонюкову, В. Голубь, В. Козакова, В. Ребкало.

Разом із тим у вітчизняній науці приділена незначна увага співвідношенню понять «державне управління», «публічне адміністрування» та «публічне управління» та обгрунтуванню необхідності переходу від концепції державного управління до публічного управління під час трансформаційних процесів України.

Постановка завдання. Метою статті $\epsilon$ аналіз співвідношення понять «державне управління», «публічне адміністрування» та «публічне управління» у трансформаційних процесах України.

Виклад основного матеріалу дослідження. Аналізуючи співвідношення понять «державне управління», «публічне адміністрування» та «публічне управління», необхідно дати визначення цих трьох понять, спільних рис та зрозуміти їх відмінності.

Так, досліджуючи поняття «державне управління», зазначимо, що в сучасному Енциклопедичному словнику 3 державного управління «державне управління» визначено як діяльність держави (органів державної влади), спрямовану на створення умов для якнайповнішої реалізації функцій держави, основних прав і свобод громадян, узгодження різноманітних груп інтересів у суспільстві та між державою і суспільством, забезпечення суспільного розвитку відповідними ресурсами $[4$, с. 150$]$.

Дослідник Г. Атаманчук характеризує державне управління як практичний, організуючий i регулюючий вплив держави (через систему своїх структур) на суспільну і приватну життєдіяльність людей із метою іiі упорядкування, збереження або перетворення, що спирається на іiі владну силу $[1$, c. 33].

В. Мартиненко визначає, що державне управління $€$ процесом здійснення авторитарного врядування через формування та реалізацію системи державних органів виконавчої влади на всіх рівнях адміністративно-територіального поділу країни, які застосовують сукупність способів, механізмів, методів владного впливу на суспільство $[9$, c. 21$]$.

За твердженням професора Т.О. Коломоєць, державне управління у вузькому розумінні - це сукупність державних органів, між якими пев- ним чином розподілені різні види діяльності держави. У широкому розумінні - це вид соціального управління, вид специфічної діяльності держави, що дістає вияв у функціонуванні iï органів, які впливають на суспільні відносини з метою ії урегулювання відповідно до державних інтересів [7].

Але 3 розвитком громадянського суспільства та поширенням демократичних цінностей зростало невдоволення громадян великою кількістю державних установ та невисокою якістю послуг, які ці установи надавали. Через це уряди розвинених країн були вимушені у XX ст. провести низку реформ, які б покращували роботу цих органів у напрямі задоволення потреб населення.

Так, традиційні механізми соціального управління трансформувалися 3 підходів «наказувати i королювати» на «мотивувати i отримувати результат».

Були визначені такі підходи управління суспільством:

- зміна традиційних піхов до управління, що базувалися на використанні владних повноважень, на більш гнучкі;

- перехід від чітких бюрократичних процедур на такі, що спрямовані на надання якісних публічних послуг.

Ці зміни призвели до появи нової форми управління в публічному секторі - «публічного адміністрування», що стало закономірним кроком у розвитку державного управління.

На відміну від державного управління, публічне адміністрування - це цілеспрямована взаємодія публічних адміністрацій з юридичними i фізичними особами 3 приводу забезпечення реалізації законів й підзаконних актів та виконання частини основних функцій: орієнтуючого планування, що визначає бажані напрями розвитку, створення правових, економічних та інших умов для реалізації інтересів учасників взаємодії, розподілу праці, кооперування і координування діяльності, моніторинг результатів [6, с. 77-78].

Якщо говорити про визначення публічного адміністрування, то воно має багато визначень. У глосарії ООН визначено, що публічне адміністрування полягає в централізованій організації виконання державної політики та програм, а також координації діяльності персоналу. Інші фахівці в галузі державного управління визначають, що публічне адміністрування пов'язане із втіленням у життя законів та інших норм, прийнятих законодавчими органами держави. Треті стверджують, що публічне адміністрування використовується в управлінській, політичній та правовій теорії 
і $є$ процедурою у виконанні дій законодавчої, виконавчої та судової гілок влади з метою здійснення державного регулювання та надання послуг населенню [3].

За даними ООН, публічне адміністрування має два тісно пов'язаних значення:

1) цілісний державний апарат (політика, правила, процедури, системи, організаційні структури, персонал тощо), який фінансується 3 державного бюджету і відповідає за управління та координацію роботи виконавчої гілки влади, і його взаємодію з іншими зацікавленими сторонами в державі, суспільстві та зовнішньому середовищі;

2) управління і реалізація всього комплексу державних заходів, що пов'язані 3 виконанням законів, постанов і рішень уряду та управління, які спрямовані на надання публічних послуг [2].

T. Кондратюк визначає публічне адміністрування як підсистему соціальної системи, складник суспільства, чиє функціонування та розвиток перебувають під потужним впливом із боку всіх інших сфер суспільної життєдіяльності [8, с. 298].

Своєю чергою, доктор наук із державного управління В.Д. Бакуменко стверджує, що «розуміння сутності державного управління зазнало еволюції внаслідок розвитку демократії та громадянського суспільства у світі та, зокрема, в Україні. Отже, нині аспект взаємодії держави і громадянського суспільства в державному управлінні $€$ дуже важливим, на відміну від традиційного бачення державного управління як організуючого й регулюючого впливу держави на суспільну життєдіяльність людей із метою іiі упорядкування, зберігання або перетворення, що спирається на iii владну силу» [4, с. 150].

Як видно з вищенаведеного, якщо співвідносити поняття «державне управління» і «публічне адміністрування», то державне управління має більш вузький характер, ключовими елементами для нього є держава і державна влада. Натомість ключовим елементами для публічного адміністрування є суспільство і публічна влада.

Незважаючи на те, що визначення державного управління і публічного адміністрування дуже схожі, основною відмінністю в них $\epsilon$ те, що державне управління належить до авторитарного виду управління, а публічне адміністрування до демократичного. У державному управлінні об'єктом виступає держава, а в публічному адмініструванні об'єктом є суспільство.

Трансформація процесів управління в державі призвела до того, що «бюрократична модель» у державному секторі регулювання (публічне адміністрування) перетворилася на розвинену модель (публічне управління). Це призвело до зміни акцентів із виконання роботи відповідно до встановлених інструкцій і чітких правил на роботу, яка забезпечує надання якісних публічних послуг і досягнення ефективних результатів. Таким чином, відбулася трансформація державного управління в публічне адміністрування, а згодом і в публічне управління.

Тобто публічне адміністрування стало перехідною ланкою або етапом, яке пройшло управління від державного до публічного.

Для кращого розуміння поняття «публічне управління» звернемося до етимології цього терміна, а саме поняття «публічне» та «управління».

Так, в Енциклопедії державного управління [5] поняття «публічний» $є$ більш ширшим ніж «державний» і містить такі дефініції, як «державний» та «суспільний, народний, загальнонародний, комунальний, відкритий, гласний». Використовуючи поняття «публічний», маємо на увазі те, що стосується органів виконавчої влади, адміністративного апарату та органів місцевого самоврядування, «суспільне; належить народові».

Поняття «управління» включає «адміністративне» і «керування, керівництво, організацію». Це значить, що публічне адміністрування є складником публічного управління, яке має на меті забезпечити розвиток держави на засадах демократії та з використанням новітніх методів і технологій управління, що покликані забезпечити громадян на рівні світових стандартів.

Щодо терміна «публічне управління» в Програмі розвитку $\mathrm{OOH}$ використовується визначення, яке запропоноване американським ученим Д.М. Шавріцом у Міжнародній енциклопедії державної політики та адміністрування: «Публічне управління - це галузь практики і теорії, яка $\epsilon$ ключовою для публічного адміністрування та зосереджена на внутрішній діяльності державних установ, зокрема на вирішенні таких управлінських питань, як контроль, керівництво, планування, організаційне постачання, забезпечення інформаційними технологіями, управління персоналом та оцінка ефективності» [3].

Своєю чергою, К. Поллітт, професор із публічного управління Лювенського католицького університету, стверджує, що термін «публічне управління» може вживатися в щонайменше трьох основних значеннях:

- діяльність державних службовців і політиків;

- структури і процедури органів державної влади; 
- системне вивчення чи то діяльності, чи то структур і процедур [10, с. 12-13].

На сучасному етапі розвитку в Україні створюються нові інституції, які через процедуру делегування отримують певний набір функцій, які неефективно використовуються органами державної влади. До цих інституцій здебільшого належать громадські організації, політичні партії, бізнес об'єднання, професійні об'єднання, спілки тощо. Такі інституції перетворюються на суб'єктів публічного управління, які активно впливають на розвиток суспільства.

Незважаючи на те, що нині співвідношення «державне управління», «публічне адміністрування» та «публічне управління» інколи губиться, а одне поняття замінюється іншим із тієї причини, що "public administration" (публічне адміністрування) та "public management” (публічне управління) перекладаються 3 англійської мови на українську як «державне управління» [2], як показує аналіз змісту понять «публічне адміністрування» та «публічне управління», правильним відповідником терміна "public management” буде «публічне управління», бо в буквальному сенсі це означає «публічний менеджмент».
Це говорить про те, що термін «державне управління» не $є$ точним відповідником терміна «публічне управління» і за своїм значенням наближений до терміна «публічне адміністрування». Основним залишається те, що ключовим аспектом державного управління $є$ держава, а ключовим аспектом публічного управління $\epsilon$ народ.

Висновки. Узагальнюючи аналіз співвідношення понять «державне управління», «публічне адміністрування» та «публічне управління», можемо зазначити, що Україна, взявши за мету європейський шлях розвитку, має рухатися шляхом розвинених країн та робити кроки 3 удосконалення моделі управління в державі. Трансформаційні процеси в Україні вимагають від неї дослідження найкращих зарубіжних тенденцій і практик, аналізу їх позитивних результатів та адаптації їх використання до національних особливостей нашої держави.

Такий підхід має сформувати модель публічного управління, яка зможе відповідати очікуванням громадян та забезпечить інтереси головних учасників суспільного процесу.

\section{Список літератури:}

1. Атаманчук Г.В. Теория государственного управления: курс лекцій. 4-е изд., дополн. Москва : Омега-Л, 2006. $584 \mathrm{c}$.

2. Босак О.3. Публічне управління як нова модель управління у державному секторі. Держсавне управління: теорія та практика : Збірник наукових праць. Харків : Вид-во «Магістр», 2010. № 2.

3. Глосарій Програми розвитку OOH. URL: http://www.unpan.org/Directories/UNPublicAdministration Glossary

4. Енциклопедичний словник з державного управління [Текст] / уклад. : Ю.П. Сурмін, В.Д. Бакуменко, А.М. Михненко та ін. ; за ред. Ю.В. Ковбасюка, В.П. Трощинського, Ю.П. Сурміна. Київ : НАДУ, 2010. $820 \mathrm{c}$.

5. Енциклопедія державного управління. [Текст] у 8 т. Т. 8. Публічне врядування / наук.-ред. кол.: В.С. Загорський [та ін.]. Львів : ЛРІДУ, НАДУ, 2011. 712 с.

6. Європеїзація публічного адміністрування в Україні в контексті європейської інтеграції : матеріали наук.-практ. конф. 17 груд. 2009 р., м. Дніпропетровськ / за заг. ред. Л.Л. Прокопенка. Дніпро : ДРІДУ НАДУ, 2009. 224 с.

7. Коломоєць Т.О. Адміністративне право України. Академічний курс : підручник. Київ : Юрінком Iнтер, 2011. 576 c. URL: http://uadocs.exdat.com/docs/index-283028.html?page=9

8. Кондратюк Т.В. Становлення порівняльного публічного адміністрування як теоретико-методологічного напряму дослідження механізмів державного управління. Науковий вісник Академії муніципального управління: Збірник наукових праць, серія «Управління». 2010. № 3. С. 297-305.

9. Мартиненко В.М. Демократичне врядування: проблеми теорії та практики. Публічне управління: теорія та практика: Збірник наук. праць. Харків : Вид-во «ДокНаукДержУпр», 2010. № 1. С. 16-22.

10. Pollitt C. Public Management Reform: A Comparative Analysis [Text] / C. Pollitt, G. Bouckaert. Oxford : University Press, 2004. 240 p.

\section{Taran Ye.I. COMPARISON BETWEEN CONCEPTS OF "GOVERNANCE", "PUBLIC ADMINISTRATION" AND "PUBLIC MANAGEMENT" \\ IN TRANSFORMATION PROCESSES OF UKRAINE}

The article analyzes comparison between the concepts of "governance", "public administration" and "public management", gives their definitions, outlines common features and differences. 
The transformation processes taking place in the Ukraine and its path to the European communitynecessitate revising the role of the state in public relations. The model of governance, which used to exist during the time of the command and administrative system, is unable to meet the needs of modern society.

The development of civil society and the spread of democratic values have caused dissatisfaction of citizens with the large number of state institutions and the poor quality of services provided by those institutions. Due to this, the governments of developed countries were forced to make a number of reforms in XX century that would improve the performance of these bodies in meeting the needs of the population. Thus, the traditional mechanisms of social governance have transformed from the approaches of "giving orders and controlling " to "motivating and producing results".

This led to emergining a new form of management in the public sector - public administration, which became a natural step in developing governance.

Although the definitions of governance and public administration are very similar, the main difference between them is that governance belongs to an authoritarian type of management, and public administration to a democratic one. The object of the governance is a state and of the public administration is a society.

Further transformation of management processes in the country led to the fact that public administration turned into a developed model of public administration.

Therefore, governance was transformed into public administration, which in turn became a stage, that management went through, from governance to public.

As a result of the conducted analysis, it was determined that transformation processes in the Ukraine require it to study the best foreign trends and practices, analyze their positive results and adapt their use to the national peculiarities of our country.

Such approach should form a model of public management that can meet expectations of the citizens and ensure the interests of the main in the society process.

Key words: governance, public administration, public management, public, management. 